are here illustrated--one a group of four, the other of two; the latter shows a straight.edged scraper above, conjoined to a simple flake below.

Hertfordshire conglomerate occurs as a surface stone at the same place, and I have at different times picked up very thin pieces without bulbs which appeared to me to have been artificially flaked. I have, however, kept no disputable objects. Hertfordshire "plum-pudding stone" was certainly flaked by the Kelts of this district, as is proved by the large, faceted and wellbulbed knife-like flake of conglomerate, found by myself at Caddington, here illustrated. This stone is not mentioned as one
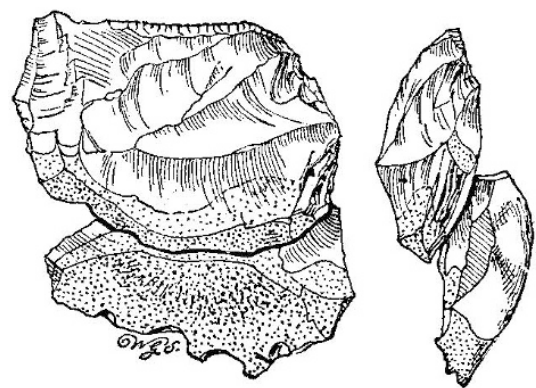

FIG. 3.-Straight edged scraper, conjoined to a flake (half actual size).

known to have been utilised for tools in the list given by Sir John Evans, in his "Stone Implements of Great Britain."

It is difficult to fix a date for the Romano-British living surface here mentioned, as the coin is too corroded for determination; but a correspondent, the Rev. Henry Cobbe, of Maulden, has a Roman coin, found in an adjoining field at Caddington, inscribed "C. Casar Aug. Germanicus." If this inscription indicates the Emperor Caligula, as Mr. Cobbe believes, we have a date, A.D. 37-4I, and the coin was probably brought over by one of the
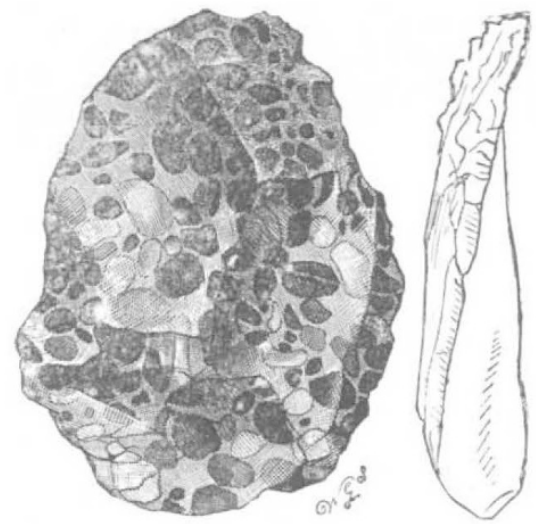

FIG. 4.-Large knife-like flake of Hertfordshire conglomerate (half actua size).

soldiers of Aulus Plautius under Claudius, in the second coming of the Romans in A.D. 43.

A short distance from the old land surface here described is an extensive Roman refuse pit with abundant broken pottery; so that it is safe to assume that a Roman villa once stood close by, and we seem to have evidence of the curious fact of a Kelt sitting down in close proximity to a Roman house and its refuse pit, quietly chipping his stone implements. It is equally curious that the impiements and detached flakes have remained undisturbed so near the surface for nearly two thousand years.

Dunstable. WORTHINGTON G. SMITH.

\section{The Bifilar Pendulum at the Royal Observatory, Edinburgh.}

Some interesting readings of the bifilar pendulum, designed by Mr. Horace Darwin for measuring movements in the earth's surface, were made here at noon on the gth inst. This instru- ment, which indicates oscillations in a north and south direction, was erected in March of last year, and daily observation of it has since been carried on, the scale being read off each minute, from five minutes before to five minutes after Paris noon. On the gth inst. nothing unusual was noticed during the first seven readings, these being all practically the same; but on putting my eye to the telescope for the eighth, I at once noticed that during the interval of less than a minute since the preceding reading, the mirror had rotated considerably about its vertical axis, the normal having moved towards the north, the difference between the seventh and eighth readings being no less than $7.6 \mathrm{~mm}$. of the scale. An immediate examination of the lamp-stand showed it to be perfectly firm. After the regular daily readings were completed, others were made at intervals of generally two minutes, for half an hour after Paris noon. These showed two quite conspicuous oscillations of the mirror during its return to its original position, which it reached about thirteen minutes after noon. It continued to move beyond this point towards the south, till at oh. $3 \mathrm{Im}$. Paris mean time it was $4^{\circ} \mathrm{I} \mathrm{mm}$. south of the point at which the scale was first read off. Later readings in the course of the day showed that it was still moving slowly to the south, but no further oscillations were recorded. In the evening, when the mirror appeared to have come to rest, the sensitiveness of the instrument was tested, and with this the column headed "Tilt of mirrorframe " in the following table has been computed. The positive sign indicates a tilt to the north.

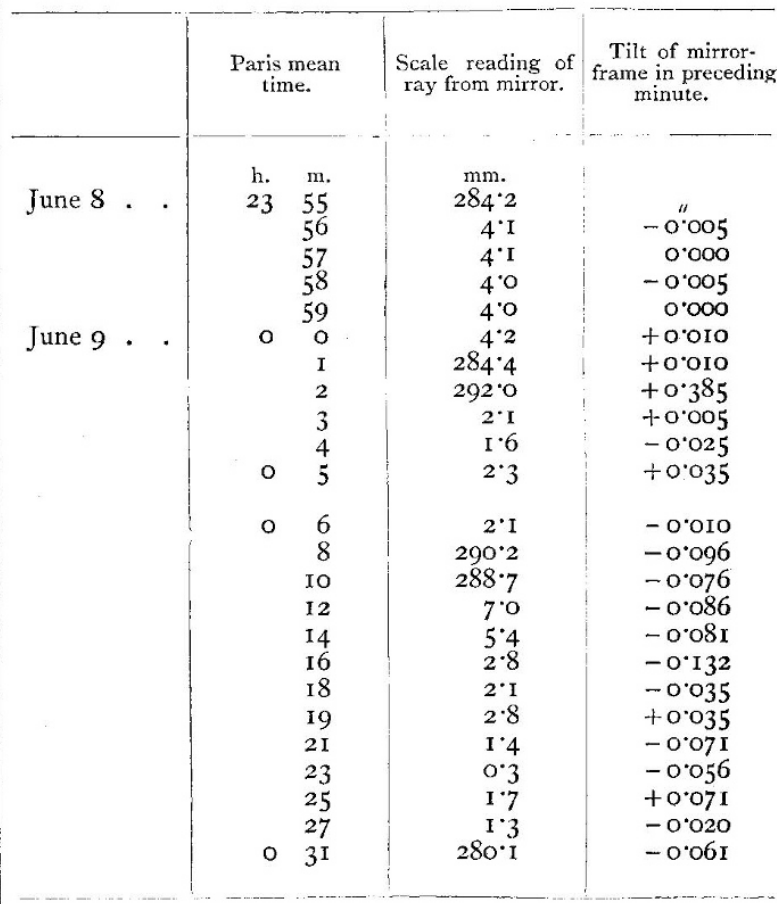

Thomas Heath.

Royal Observatory, Calton Hill, Edinburgh, June 20.

\section{Migration of a Water-beetle.}

LAST night, at about ten o'clock, a beetle flew in through the open window, alighting on a bowl of roses in the centre of the dining table. On being dropped into a finger-bowl he promptly dived and swam merrily, and proved to be a specimen of the ordinary brown water-beetle, to be found in every pond or ditch of water. Now the nearest water to my dining-room window is the Thames, distant over a quarter of a mile as the crow flies, whence this water-beetle must have flown. Can any of your readers inform me whether such long flights have been observed before in connection with the pairing season or migration of this species? I enclose you a rough sketch of the beetle, not knowing its specific title amongst the Coleoptera.

Basildon, Reading, June 23.
Rose HaIg Thomas.

No. I 340 , VOL. 52] 